\title{
Carers' concern for older people falling at home: an integrative review
}

Seng Giap Marcus $\underline{\text { Ang }^{1} \text {, BSc(Hons), PhD, Anthony Paul O’Brien }}{ }^{2}$, PhD, RN, Amanda $\underline{\text { Wilson }}^{2}$, MCA, PhD

Falls, the leading cause of injury and death among older people, can have a significant psychosocial impact on carers. Carers play a crucial role in caring for older persons at home and in fall prevention. This review, which included 15 studies, aimed to identify carers' concern about older people falling and its impact. We identified that most carers had concerns about repeated falls in older people, unknown consequences of falls and care recipients' non-adherence to fall prevention advice. These concerns, in turn, affect carers' physical and psychological health, lifestyle, caregiving burden and use of fall prevention strategies. This paper highlights the importance of recognising carers' fall concern so as to identify carers' needs and awareness of fall prevention in older people living at home. Greater insight into carers' fall concern could facilitate the implementation of new strategies to manage older people's fall risk as well as improve carers' well-being.

Keywords: carers, fall concern, fall prevention, integrative review, older people

\section{INTRODUCTION}

Accidental falls are the leading cause of injury deaths globally, especially among older people. (1) Approximately 28\% to $35 \%$ of older people aged 65 years and older fall each year, with the incidence of falls increasing with age and frailty. ${ }^{(2)}$ Globally, 646,000 people die annually as a result of falls and 37.3 million falls require medical attention. (1) Besides physical injury, falls have a significant psychological and social impact on older people, including fear of falling, loss of confidence in their balance and activity restriction. ${ }^{(3)}$

As the world's ageing population increases, more carers are needed to enable older people to continue living in their own home. ${ }^{(4)}$ In 2011, there were about 6.5 million carers in the United Kingdom and that number is projected to increase to 9 million by 2037. ${ }^{(5)}$ In the United States of America (USA), it is estimated that 34.2 million carers provide unpaid care to people aged over 50 years. ${ }^{(6)}$ In Australia, almost 2.7 million Australians were identified as carers in 2015. ${ }^{(7)}$

Unpaid carers, usually family or friends, contribute significantly in terms of time and effort to caring for older people in their homes. In many parts of Asia, it is a cultural norm for children to look after their parents. ${ }^{(8)}$ For instance, in Singapore, government housing grants have been introduced since 1978 to encourage children to live with or near to their parents, ${ }^{(9,10)}$ and about $10 \%$ of Singaporean households currently comprise three generations (3G) or more families living together (e.g. an elderly married couple living with their children and grandchildren). ${ }^{(11)}$ Between 2000 and 2014, 3G households in Singapore with at least one member aged 65 years and older increased from 62,800 to $82,100 .{ }^{(11)}$ The roles of caring for an older person are extensive, ranging from providing assistance in activities of daily living to management of healthcare. ${ }^{(7)}$ As people age, they experience concomitant physical (and cognitive) decline, which increases their risk of falls and need for increased fall vigilance. Falls among older people at home generally increase a carer's burden. This is particularly the case as care needs increase and there is continued concern about the potential for ongoing falls. ${ }^{(12-14)}$

Furthermore, carers are a trusted source of information, and well placed to negotiate, engage and initiate strategies to prevent the older person from falling at home. ${ }^{(15)} \mathrm{A}$ randomised controlled trial found that carers who engaged in fall prevention programmes had significant improvement in fall risk awareness and fall prevention strategies for older adults with cancer. ${ }^{(16)}$ Another study on the efficacy of a home-based, carer-enhanced exercise programme found significant improvement in balance, fall concern and physical activity among older people living with dementia. ${ }^{(17)}$ Conversely, carers can inadvertently escalate the risk of older people falling. In an attempt to prevent falls at home, a carer may try to limit the older person's activities, leading to increased dependence. ${ }^{(18)} \mathrm{A}$ longitudinal study in long-term care facilities found that professional carers' fall concern for residents with dementia was predictive of restraint use, future functional ability and injurious falls. ${ }^{(19)}$

While there is a growing body of evidence on the impact of carers' concern for older people falling, there is no integrated knowledge regarding this concern. A comprehensive overview of aspects influencing carers' concern for older people falling has the potential to improve future fall prevention programmes by tailoring preventive strategies to older people and their carers. The search questions that are specific to this review are: (a) What are the causes of carers' concern about older people falling? (b) What is the impact of fall concern on the carers and how does this concern influence fall prevention strategies?

\section{METHODS}

Evidence was synthesised using the integrative review method. This method combines different methodologies to provide a

${ }^{1}$ School of Nursing and Midwifery, Edith Cowan University, Joondalup, ${ }^{2}$ School of Nursing and Midwifery, Faculty of Health and Medicine, The University of Newcastle, Callaghan, Australia

Correspondence: Dr Seng Giap Marcus Ang, Lecturer (Nursing), School of Nursing and Midwifery, Edith Cowan University, 270 Joondalup Drive, Joondalup WA 6027, Australia. s.ang@ecu.edu.au 


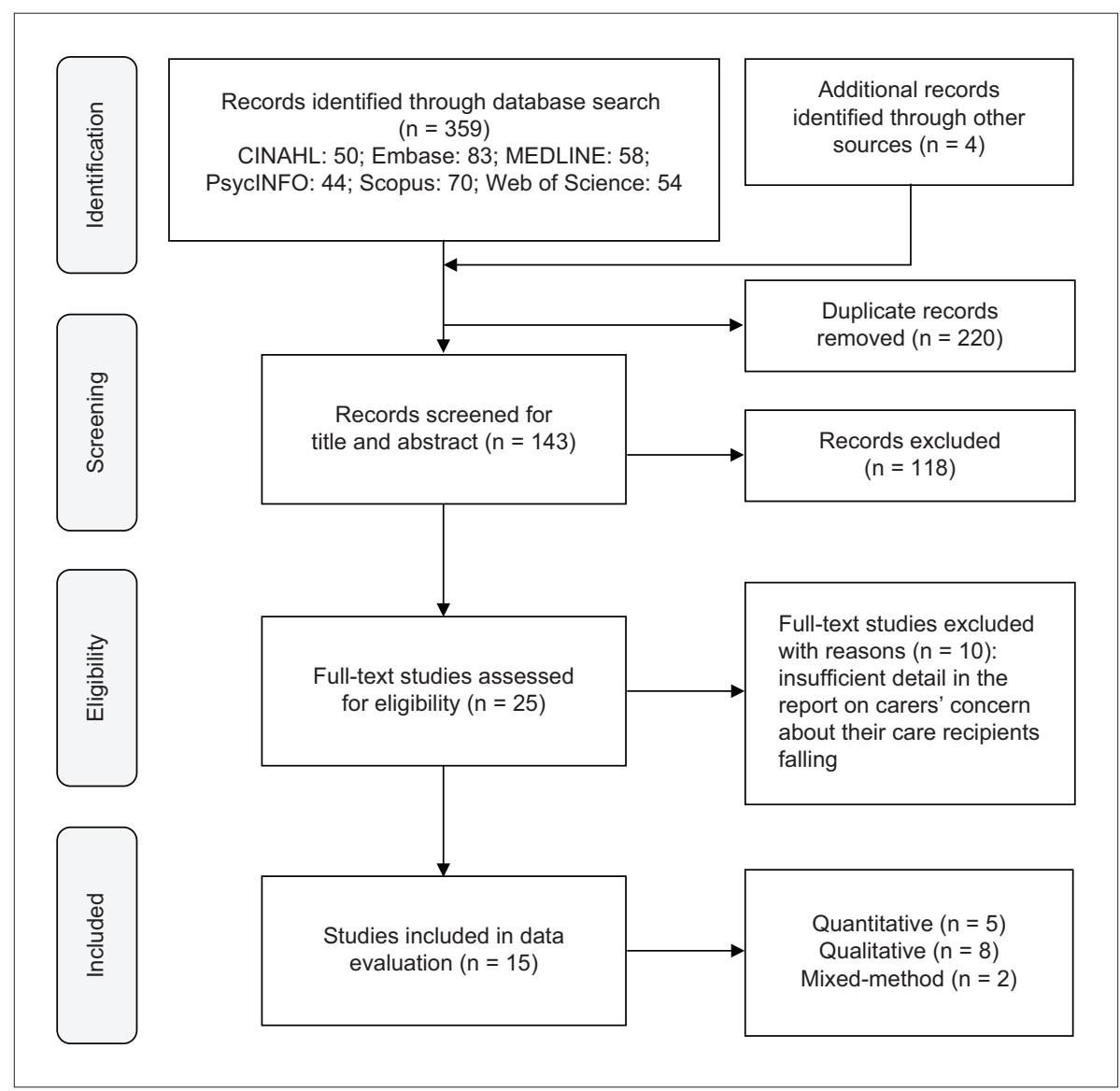

Fig. 1 Chart shows the search strategy and procedures used to identify the studies.

holistic understanding about carers' concern for older people falling and informs evidence-based practice regarding fall prevention at home. ${ }^{(20)}$

\section{Search strategy}

A systematic search was conducted in CINAHL, Embase, MEDLINE, PsycINFO, Scopus and Web of Science. Additional records were identified by hand searching reference lists of the selected studies. Search terms included: 'caregiver', OR 'carer', OR 'support person', AND 'fall efficacy', OR 'fear of falling', OR 'worry of falling', OR 'concern of falling'. Search strategies were modified according to individual databases. Proximity searches and truncation to identify terms in their adjectival form were used. The full search strategy for all databases is presented in the supplementary table (Appendix, Supplementary Table I).

Inclusion criteria for the review were empirical studies published in English between January 1993 and September 2018 exploring carers' concern for older people falling at home, with a focus on the general older population or those with age-related chronic illnesses. In this review, a 'carer' is defined as an individual providing informal ambulation support and activities of daily living assistance to an older person living at home. Studies that focused on professional carers, falls that occurred in the hospitals or nursing homes, or falls related to paediatric population were excluded from the literature search.

\section{Search outcomes}

The initial search yielded a total of 359 studies. After the removal of 220 duplicates, 143 studies, including four additional studies identified from the reference lists of the remaining studies, were reviewed using their title and abstract. Based on the inclusion criteria, 25 studies were selected for full-text review. Ten studies were excluded due to insufficient detail on carers' concern about their care recipients falling, such as evaluation of this concern, its causative factors, and its impact on the carers and older person. Finally, 15 studies were used for this integrative review. The search strategy and procedures were conducted according to the Preferred Reporting Items for Systematic Reviews and Meta-analyses framework (Fig. 1).

\section{Quality appraisal}

The systematic search resulted in 15 studies: five quantitative, eight qualitative and two mixed-method studies relating to carers' concern for falls in older persons. Methodological quality of the included studies was assessed using the 17-criteria Mixed Methods Appraisal Tool (Table I). ${ }^{(21)}$ All 15 studies fulfilled the screening criteria by having research methodologies that were congruent to the study aims.

Among the eight qualitative studies, four applied grounded theory, ${ }^{(12,13,22,23)}$ three were descriptive designs ${ }^{(24-26)}$ and one used focus groups. ${ }^{(27)}$ All studies had relevant qualitative data sources and analyses, and appropriately addressed the study findings to the context. Only two studies appropriately considered potential researcher bias. ${ }^{(23,24)}$ 
Review Article

Table I. Methodological quality of included studies.

\begin{tabular}{|c|c|c|c|c|c|c|c|c|c|c|c|c|c|c|c|}
\hline \multirow[t]{3}{*}{ Quality criteria } & \multirow{2}{*}{\multicolumn{8}{|c|}{ Qualitative studies }} & \multicolumn{5}{|c|}{ Quantitative studies } & \multirow{2}{*}{\multicolumn{2}{|c|}{$\begin{array}{l}\text { Mixed-methods } \\
\text { studies }\end{array}$}} \\
\hline & & & & & & & & & \multirow{2}{*}{\begin{tabular}{l}
\multicolumn{1}{|c|}{ RCT } \\
Faes \\
et al ${ }^{(28)}$
\end{tabular}} & \multicolumn{4}{|c|}{ Non-randomised } & & \\
\hline & $\begin{array}{l}\text { Abendroth } \\
\text { et al } \mathrm{I}^{(22)}\end{array}$ & $\begin{array}{l}\text { Buri \& } \\
\text { Dawson }^{(23)}\end{array}$ & $\begin{array}{l}\text { Davey } \\
\text { et al }\left.\right|^{(13)}\end{array}$ & $\begin{array}{l}\text { Faes } \\
\text { et al }{ }^{(12)}\end{array}$ & $\begin{array}{l}\text { Habermann } \\
\& \text { Shin }^{(26)}\end{array}$ & $\begin{array}{l}\text { Kelley } \\
\text { et al }{ }^{(24)}\end{array}$ & $\begin{array}{l}\text { Peach } \\
\text { et } \mathrm{al}^{(25)}\end{array}$ & $\begin{array}{l}\text { Stevenson } \\
\text { \& Taylor }\end{array}$ & & $\begin{array}{l}\text { Forster \& } \\
\text { Young(29) }\end{array}$ & $\begin{array}{l}\text { Kuzuya } \\
\text { et al }{ }^{(14)}\end{array}$ & $\begin{array}{l}\text { Liddle \& } \\
\text { Gilleard( }^{(30)}\end{array}$ & $\begin{array}{l}\text { Meyer } \\
\text { et } \mathrm{al}^{(31)}\end{array}$ & $\begin{array}{l}\text { Dow } \\
\text { et al }\left.\right|^{(32)}\end{array}$ & $\begin{array}{l}\text { Honaker \& } \\
\text { Kretschmer }^{(18)}\end{array}$ \\
\hline Clear objectives & $\sqrt{ }$ & $\sqrt{ }$ & $\sqrt{ }$ & $\sqrt{ }$ & $\sqrt{ }$ & $\sqrt{ }$ & $\sqrt{ }$ & $\sqrt{ }$ & $\sqrt{ }$ & $\sqrt{ }$ & $\sqrt{ }$ & $\sqrt{ }$ & $\sqrt{ }$ & $\sqrt{ }$ & $\sqrt{ }$ \\
\hline $\begin{array}{l}\text { Appropriate data } \\
\text { collection }\end{array}$ & $\sqrt{ }$ & $\sqrt{ }$ & $\sqrt{ }$ & $\sqrt{ }$ & $\sqrt{ }$ & $\sqrt{ }$ & $\sqrt{ }$ & $\sqrt{ }$ & $\sqrt{ }$ & $\sqrt{ }$ & $\sqrt{ }$ & $\sqrt{ }$ & $\sqrt{ }$ & $\sqrt{ }$ & $\sqrt{ }$ \\
\hline $\begin{array}{l}\text { Relevant data } \\
\text { sources }\end{array}$ & $\sqrt{ }$ & $\sqrt{ }$ & $\sqrt{ }$ & $\sqrt{ }$ & $\sqrt{ }$ & $\sqrt{ }$ & $\sqrt{ }$ & $\sqrt{ }$ & & & & & & $\sqrt{ }$ & $\sqrt{ }$ \\
\hline $\begin{array}{l}\text { Relevant data } \\
\text { analysis }\end{array}$ & $\sqrt{ }$ & $\sqrt{ }$ & $\sqrt{ }$ & $\sqrt{ }$ & $\sqrt{ }$ & $\sqrt{ }$ & $\sqrt{ }$ & $\sqrt{ }$ & & & & & & $\sqrt{ }$ & $\sqrt{ }$ \\
\hline Appropriate setting & $\sqrt{ }$ & $\sqrt{ }$ & $\sqrt{ }$ & $\sqrt{ }$ & $\sqrt{ }$ & $\sqrt{ }$ & $\sqrt{ }$ & $\sqrt{ }$ & & & & & & $\sqrt{ }$ & $\sqrt{ }$ \\
\hline $\begin{array}{l}\text { Researcher } \\
\text { influence } \\
\text { considered }\end{array}$ & $x$ & $\sqrt{ }$ & $x$ & $x$ & $x$ & $\sqrt{ }$ & $x$ & $x$ & & & & & & $x$ & $\sqrt{ }$ \\
\hline $\begin{array}{l}\text { Clear } \\
\text { randomisation } \\
\text { description }\end{array}$ & & & & & & & & & $\sqrt{ }$ & & & & & & \\
\hline $\begin{array}{l}\text { Blinding when } \\
\text { applicable }\end{array}$ & & & & & & & & & $\sqrt{ }$ & & & & & & \\
\hline $\begin{array}{l}\text { Outcome data } \\
>80 \%\end{array}$ & & & & & & & & & $\sqrt{ }$ & & & & & & \\
\hline Dropout $<20 \%$ & & & & & & & & & $\sqrt{ }$ & & & & & & \\
\hline $\begin{array}{l}\text { Minimise selection } \\
\text { bias }\end{array}$ & & & & & & & & & & $\sqrt{ }$ & $\sqrt{ }$ & $\sqrt{ }$ & $\sqrt{ }$ & $\sqrt{ }$ & $\sqrt{ }$ \\
\hline $\begin{array}{l}\text { Appropriate } \\
\text { measurements }\end{array}$ & & & & & & & & & & $\sqrt{ }$ & $\sqrt{ }$ & $\sqrt{ }$ & $\sqrt{ }$ & $\sqrt{ }$ & $\sqrt{ }$ \\
\hline $\begin{array}{l}\text { Comparable } \\
\text { participants }\end{array}$ & & & & & & & & & & $\sqrt{ }$ & $\sqrt{ }$ & $\sqrt{ }$ & $\sqrt{ }$ & $\sqrt{ }$ & $\sqrt{ }$ \\
\hline $\begin{array}{l}\text { Response rate } \\
>60 \%\end{array}$ & & & & & & & & & & $\sqrt{ }$ & $\sqrt{ }$ & $\sqrt{ }$ & $x$ & $\sqrt{ }$ & $\sqrt{ }$ \\
\hline $\begin{array}{l}\text { Relevant research } \\
\text { design }\end{array}$ & & & & & & & & & & & & & & $\sqrt{ }$ & $\sqrt{ }$ \\
\hline $\begin{array}{l}\text { Relevant mixed } \\
\text { method integration }\end{array}$ & & & & & & & & & & & & & & $x$ & $\sqrt{ }$ \\
\hline $\begin{array}{l}\text { Integration } \\
\text { limitation } \\
\text { considered }\end{array}$ & & & & & & & & & & & & & & $x$ & $x$ \\
\hline
\end{tabular}

RCT: randomised control trial 
Of the five quantitative studies, one was a randomised controlled trial, ${ }^{(28)}$ two were cohort studies, ${ }^{(29,30)}$ and the rest used a cross-sectional design. ${ }^{(14,31)}$ Methodological quality of the randomised controlled trial was robust, fulfilling all the criteria related to randomisation description, blinding, completed outcome data $>80 \%$ and low dropout rate. ${ }^{(28)}$ The other four quantitative studies also achieved minimisation of selection bias, applied appropriate measurements and recruited comparable participants. One study did not obtain an acceptable response rate of more than $60 \%{ }^{(31)}$ as required by the Mixed Methods Appraisal Tool. However, for the purpose of identifying additional factors related to carers' concern, that study was included, as it explored the relationship between care recipients' fall risk and caring burden.

Both the mixed-method studies used a prospective longitudinal design for the quantitative component. For the qualitative component, one study applied a focus group, ${ }^{(32)}$ while the other study used face-to-face interviews. ${ }^{(18)}$ Methodological quality for individual quantitative and qualitative components was robust, with both studies fulfilling most of the quality criteria. However, only one study demonstrated appropriate integration of qualitative and quantitative data. ${ }^{(18)}$

\section{Data extraction}

A narrative analysis was used to review evidence related to the phenomenon of carers' fall concern. Data was extracted using a data reduction method to facilitate systematic comparison of primary studies and understanding of the relationship between each theme and the phenomenon of concern. ${ }^{(20)}$ Seven studies were used to describe the causes for carers' concern about older people falling. Findings were extracted and grouped into two themes: prevalence and measurement of fall concern; and carers' fall concerns. 13 studies provided findings on the impact of fall concern. These findings were pooled and categorised into four themes: impact on physical and psychological health; lifestyle changes; increased caregiving burden; and impact on fall prevention strategies used. A summary of these studies is provided in Table II.

\section{RESULTS}

Across the 15 studies, the sample size for carers ranged from ten to 1,478 and that for care recipients from ten to 1,874 . Mean age of the carers and care recipients was $61.3-72.1$ years and 65.4-78.5 years, respectively. In most studies, the carers were either children or spouses of the care recipients. ${ }^{(12,13,18,22-24,26,27,29)}$ Only one study was conducted in a non-Western country. ${ }^{(14)}$ Not all the studies were conducted in the general older population; there were three studies each focusing on carers of older people with Parkinson's disease ${ }^{(13,22,26)}$ and dementia, ${ }^{(23,25,27)}$ and two studies on carers looking after stroke patients. ${ }^{(24,29)}$

\section{Prevalence and measurement of fall concern}

Three quantitative studies explored the prevalence of carers' concern about the older persons falling. ${ }^{(28-30)}$ Among older people with a history of falls in the community, between $58 \%$ and $91 \%$ of their carers reported being fearful that their care recipients would fall again. ${ }^{(28,30)}$ In a quantitative study of older people with stroke who were discharged from hospital, many carers were concerned about their care recipients falling regardless of whether they had fallen previously, and 57\% (42/74) and 45\% (33/74) of these carers continued to experience fall concern at the eight-week and six-month follow-up, respectively. ${ }^{(29)}$ To measure carers' concern for their care recipients falling, two studies used a single-item question with 'yes' or 'no' response, ${ }^{(28,29)}$ and one study used a three-point scale of 'no fear', 'some fear' and 'great fear'. ${ }^{(30)}$ No aspects of validity and reliability were tested for any single-item measures.

\section{Carers' fall concerns}

Two studies reported carers' concerns about the outcomes of falls in care recipients. ${ }^{(12,13)}$ While the possibility of older people falling was the main concern of carers, there is evidence suggesting that carers are equally distressed over other consequences of a fall. A qualitative study on carers whose spouses with Parkinson's disease experienced recurrent falls found that their concerns exceeded the immediate consequences of the fall, to the possible impact on the older person's quality of life and survival. ${ }^{(13)}$ Carers of frail older people also described fear about the unknown consequences of a fall, such as fractures or hospitalisation, regardless of the frequency of previous falls. ${ }^{(12)}$

Four studies discussed carers' concern about the older person's lack of awareness of their fall risk and their continued engagement in high-risk activities, exposing them to the potential of falling. ${ }^{(12,13,24,32)} \mathrm{A}$ focus group of carers from the general elderly population found that care recipients forgetting their mobility aids or refusing to use them were common causes of concern among carers. ${ }^{(32)}$ A similar concern was highlighted by the spouses of stroke survivors when the older persons chose to walk without their prescribed walking aids. ${ }^{(24)}$

Furthermore, Faes et al reported that carers of older people with cognitive impairment experienced emotional distress when their care recipients refused to adhere to their fall prevention advice. ${ }^{(12)}$ As a result, carers often felt that the falls were beyond their control and could not be prevented. Carers of older people with Parkinson's disease also attributed the causes of falls and their concern to the care recipients' risk-taking behaviour, which was complicated by the older persons' desire for independence. ${ }^{(13)}$

\section{Impact on physical and psychological health}

Only one study reported on carers who injured themselves while trying to stop their spouses from falling, or when helping them up from a fall. ${ }^{(13)}$ Due to the common occurrence of falls, some carers were reluctant to seek help despite lacking the physical strength to lift their spouse up from a fall, which put the carers at further risk of personal injury. ${ }^{(13)}$

The psychological impact of an older person's fall was explored in four studies..$^{(13,29,31,32)}$ Forster and Young found that carers of older people with stroke were significantly more stressed if their care recipients had fallen six months after hospital discharge. ${ }^{(29)}$ Among the general elderly population, carers of care 
Review Article

Table II. Summary of review of selected literature to carers' fall concern.

\begin{tabular}{|c|c|c|c|c|c|}
\hline Study; country & Study aim & Study type & Carer & Care recipient & Related to theme(s) in review \\
\hline \multicolumn{6}{|l|}{ Qualitative } \\
\hline $\begin{array}{l}\text { Abendroth et } \mathrm{al}_{i}^{(22)} \\
\text { USA }\end{array}$ & $\begin{array}{l}\text { Understand carers' experience of caring for } \\
\text { family member with Parkinson's disease and } \\
\text { decision for placement in long-term care }\end{array}$ & $\begin{array}{l}\text { Grounded theory using } \\
\text { semi-structured interviews }\end{array}$ & $\begin{array}{l}17 \text { females and } 3 \text { males; } \\
\text { caring for spouse or parent }\end{array}$ & - & Increased caregiving burden \\
\hline $\begin{array}{l}\text { Buri \& Dawson; }{ }^{(23)} \\
\text { UK }\end{array}$ & $\begin{array}{l}\text { Explore the perspective of fall risk among } \\
\text { carers of elderly with dementia }\end{array}$ & $\begin{array}{l}\text { Grounded theory using } \\
\text { focus group and one-to-one } \\
\text { interviews }\end{array}$ & $\begin{array}{l}7 \text { carers for focus group } \\
\text { and } 6 \text { carers for one-to-one } \\
\text { interview; caring for spouse } \\
\text { or parent }\end{array}$ & - & $\begin{array}{l}\text { Impact on fall prevention strategies } \\
\text { used }\end{array}$ \\
\hline Davey et al; ${ }^{(13)}$ UK & $\begin{array}{l}\text { Explore the views of informal carers of } \\
\text { repeat fallers with Parkinson's disease }\end{array}$ & $\begin{array}{l}\text { Grounded theory using } \\
\text { semi-structured interviews }\end{array}$ & $\begin{array}{l}11 \text { females and } 3 \text { males; } \\
\text { caring for spouse; mean age } \\
69.9 \mathrm{yr}\end{array}$ & - & $\begin{array}{l}\text { Carers' fall concerns; impact on physical } \\
\text { and psychological health; lifestyle } \\
\text { changes; impact on fall prevention } \\
\text { strategies used }\end{array}$ \\
\hline $\begin{array}{l}\text { Faes et al; }{ }^{(12)} \\
\text { Netherlands }\end{array}$ & $\begin{array}{l}\text { Explore the impact of fall for frail } \\
\text { community-dwelling older persons and } \\
\text { their family carers and define future fall } \\
\text { prevention programme }\end{array}$ & $\begin{array}{l}\text { Grounded theory using } \\
\text { interviews }\end{array}$ & $\begin{array}{l}5 \text { females and } 5 \text { males; } \\
\text { caring for spouse or parent; } \\
\text { mean age } 66.5 \mathrm{yr}\end{array}$ & $\begin{array}{l}6 \text { females and } 4 \\
\text { males; mean age } \\
78.5 \mathrm{yr}\end{array}$ & $\begin{array}{l}\text { Carers' fall concerns; lifestyle changes; } \\
\text { increased caregiving burden; impact on } \\
\text { fall prevention strategies used }\end{array}$ \\
\hline $\begin{array}{l}\text { Habermann \& Shin;(26) } \\
\text { USA }\end{array}$ & $\begin{array}{l}\text { Explore the needs, concerns and preferences } \\
\text { of couples with advanced stage Parkinson's } \\
\text { disease }\end{array}$ & $\begin{array}{l}\text { Descriptive qualitative } \\
\text { study using semi-structured } \\
\text { interviews }\end{array}$ & $\begin{array}{l}7 \text { females and } 7 \text { males; } \\
\text { caring for spouse; } \\
\text { mean age } 72.1 \mathrm{yr}\end{array}$ & $\begin{array}{l}7 \text { females and } \\
7 \text { males; } \\
\text { mean age } 73.3 \mathrm{yr}\end{array}$ & $\begin{array}{l}\text { Lifestyle changes; increased caregiving } \\
\text { burden }\end{array}$ \\
\hline $\begin{array}{l}\text { Kelly et al; }{ }^{(24)} \\
\text { USA }\end{array}$ & $\begin{array}{l}\text { Explore the lived experiences of stroke } \\
\text { survivors and their spouses about falling } \\
\text { and general mobility }\end{array}$ & $\begin{array}{l}\text { Qualitative study using } \\
\text { semi-structured interviews }\end{array}$ & $\begin{array}{l}104 \text { females and } 29 \text { males; } \\
\text { caring for spouse; mean age } \\
61.3 \mathrm{yr}\end{array}$ & $\begin{array}{l}29 \text { females and } 104 \\
\text { males; mean age } \\
65.4 \mathrm{yr}\end{array}$ & $\begin{array}{l}\text { Carers' fall concerns; increased } \\
\text { caregiving burden }\end{array}$ \\
\hline Peach et al; ${ }^{(25)}$ UK & $\begin{array}{l}\text { Explore the perceptions of older people with } \\
\text { mild dementia/cognitive impairment, and } \\
\text { their family carers about fall, fall risk and fall } \\
\text { prevention }\end{array}$ & $\begin{array}{l}\text { Qualitative study using } \\
\text { semi-structured interviews }\end{array}$ & $\begin{array}{l}21 \text { relatives caring for } \\
\text { spouse, parent, grandparent } \\
\text { or friend }\end{array}$ & $\begin{array}{l}7 \text { females and } 13 \\
\text { males; mean age } \\
70-93 \text { yr }\end{array}$ & $\begin{array}{l}\text { Lifestyle changes; impact on fall } \\
\text { prevention strategies used }\end{array}$ \\
\hline $\begin{array}{l}\text { Stevenson \& Taylor; } \\
\text { Northern Ireland }\end{array}$ & $\begin{array}{l}\text { Explore the experiences and concepts of } \\
\text { risk from the perspective of family carers of } \\
\text { older people with dementia }\end{array}$ & $\begin{array}{l}\text { Qualitative study using focus } \\
\text { groups }\end{array}$ & $\begin{array}{l}16 \text { females and } 6 \text { males; } \\
\text { caring for spouse or parent }\end{array}$ & - & $\begin{array}{l}\text { Impact on fall prevention strategies } \\
\text { used }\end{array}$ \\
\hline \multicolumn{6}{|c|}{ Quantitative: randomised controlled trial } \\
\hline $\begin{array}{l}\text { Faes et al:(28) } \\
\text { Netherlands }\end{array}$ & $\begin{array}{l}\text { Assess the efficacy of fall prevention } \\
\text { programme in preventing falls and fear } \\
\text { of falling in frail older fallers and reducing } \\
\text { caregiver burden }\end{array}$ & $\begin{array}{l}\text { Randomised, parallel-group, } \\
\text { single-blind trial }\end{array}$ & $\begin{array}{l}19 \text { females and } 14 \text { males; } \\
\text { caring for spouse, parent or } \\
\text { others }\end{array}$ & $\begin{array}{l}23 \text { females and } 10 \\
\text { males; mean age } \\
78.3 \mathrm{yr}\end{array}$ & $\begin{array}{l}\text { Prevalence and measurement of fall } \\
\text { concern }\end{array}$ \\
\hline \multicolumn{6}{|c|}{ Quantitative: non-randomised } \\
\hline $\begin{array}{l}\text { Forster \& Young; }{ }^{(29)} \\
\text { UK }\end{array}$ & $\begin{array}{l}\text { Investigate the incidence and consequences } \\
\text { of falls in elderly with stroke following } \\
\text { discharge }\end{array}$ & $\begin{array}{l}\text { Cohort study, follow-up at } \\
8 \text { wk and } 6 \mathrm{mth}\end{array}$ & $\begin{array}{l}74 \text { carers; caring for spouse } \\
\text { or relative }\end{array}$ & $\begin{array}{l}51 \text { females and } 57 \\
\text { males; median age } \\
70 \mathrm{yr}\end{array}$ & $\begin{array}{l}\text { Prevalence and measurement of fall } \\
\text { concern; impact on physical and } \\
\text { psychological health; lifestyle changes }\end{array}$ \\
\hline $\begin{array}{l}\text { Kuzuya et al; }{ }^{(14)} \\
\text { Japan }\end{array}$ & $\begin{array}{l}\text { Determine the association between care } \\
\text { recipients' falling and caregivers' burden }\end{array}$ & $\begin{array}{l}\text { Cross-sectional study using } \\
\text { self-reported questionnaire }\end{array}$ & $\begin{array}{l}1,478 \text { carers; caring for } \\
\text { spouse, parent or others }\end{array}$ & $\begin{array}{l}1,242 \text { females and } \\
632 \text { males }\end{array}$ & Increased caregiving burden \\
\hline
\end{tabular}




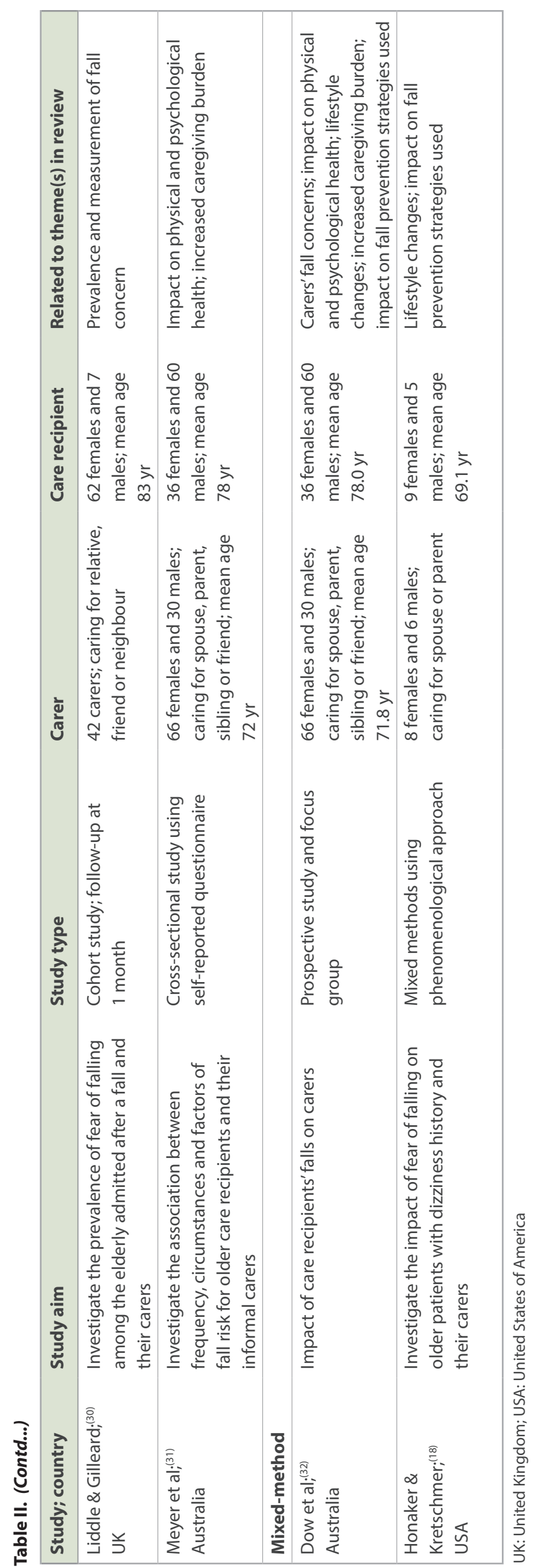

recipients with a high fall risk expectation experienced higher levels of depression. ${ }^{(31)}$ Another study revealed from qualitative interviews that carers experienced mixed feelings of emotional and psychological consequences such as anxiety, worry, fear, shock, anger and frustration due to their care recipients falling. ${ }^{(13)}$ Dow et al concluded that some carers blamed themselves for not monitoring their care recipients closely enough. ${ }^{(32)}$

\section{Lifestyle changes}

Seven studies discussed carers' social restrictions related to the older person falling at home. ${ }^{(12,13,18,25,26,29,32)}$ Fear of older people falling meant carers had to be constantly vigilant and avoid leaving the care recipient alone. ${ }^{(12,13,32)}$ One study reported that carers would only leave their spouses for brief periods, or when someone else was available to supervise their spouses in their absence. ${ }^{(26)}$ The reluctance to leave the older persons alone limited the carers' opportunity to participate in individual or social activities, leading to social withdrawal. ${ }^{(12,13,18,29)}$ Carers also reported changing their daily routines, such as work arrangements and social engagements, to facilitate greater supervision of the older person after a fall. ${ }^{(25,32)}$

\section{Increased caregiving burden}

The literature search identified seven studies that discussed the carers' experience of increased burden related to caring for older people at risk of falling. ${ }^{(12,14,22,24,26,31,32)}$ Besides having to ensure their care recipients' safety, some carers also experienced a change in the level of care; this could be due to the older persons requiring more help in mobility or daily activities, or the carers having to attend to their care recipients' injuries after a fall. ${ }^{(32)}$ As a result, more time was needed to assist the older person, and carers were often unable to complete their chores or get enough rest. This lack of time and energy was also explored in a qualitative study among spouses of stroke survivors. ${ }^{(24)}$ The theme 'time is constantly on my mind' emerged from the interviews as carers described difficulty fulfilling work and home responsibilities while looking after their spouses. According to Faes et al, carers of frail older people experienced increasing burden as they became more aware of their care recipients' dependence, and many carers also felt fatigue and overwhelmed by the changes in caring roles and duties. ${ }^{(12)}$

The relationship between falls and caregiving burden was examined in two Australian quantitative studies, which found a significant increase in general caregiving burden for carers looking after older people with a higher fall risk ${ }^{(31)}$ and those who had fallen once in 12 months. ${ }^{(32)} \mathrm{A}$ Japanese study using a large cross-sectional sample of 1,478 carers also found that carers of older people who had fallen in the past six months had a significantly higher caregiving burden than those caring for non-fallers. ${ }^{(14)}$

When carers' burden of care exceeds their ability to provide adequate care, the care recipients who had experienced a fall often end up being placed in institutional care. ${ }^{(22)}$ Carers identified falls with severe injury as one of the main reasons for sending their family members with Parkinson's disease to long-term care. Yet, falls are an accepted part of Parkinson's disease progression, 
and carers are not always able to minimise the risk of their care recipients falling. To mitigate this burden, some carers turned to respite care for support. However, in the studies reviewed, respite care was sometimes met with reservations due to either the carers' previous bad experience or the care recipients' refusal to accept care. ${ }^{(26,32)}$

\section{Impact on fall prevention strategies used}

Caregivers' fall concern has an influence on the strategies used for fall prevention at home, and this was discussed in seven studies. ${ }^{(12,13,18,23,25,27,32)}$ Six of these studies described carers who stayed vigilant in order to prevent older people from falling. ${ }^{(12,13,23,25,27,32)}$ Some strategies included frequent telephone calls or visitations, close monitoring of care recipients' activities, constant reminders and awareness of their individual fall risk. Other carers used strategies such as giving advice on posture and walking, promoting physical activity or attendance at rehabilitation clinics, encouraging the use of walking aids, and making changes to the home environment. ${ }^{(12,13,27,32)}$ Besides preventing possible falls, carers also resorted to modifications of the home environment, such as installation of grab rails/sensor lights and removal of mats, to minimise the potential impact of a fall occurring. ${ }^{(13)}$

Due to concerns about older people's risk of falling, some carers chose to accompany their care recipients to social activities or assist them in their chores. ${ }^{(12)}$ However, one study found that carers of older people with dementia do not always want to undermine their care recipients' independence with over-support. ${ }^{(25)}$ Stevenson and Taylor stated that carers generally do not wish to restrict their care recipients from participating in their daily activities, despite the risks involved.(27) They further suggested that the risk would be worth it if their older care recipient could get out of the house, be mentally stimulated or experience some enjoyment from being cared for in a flexible environment. Some carers, however, tried to intervene by taking over or by restricting activities that are perceived to be risky. ${ }^{27}$ Buri and Dawson reported that, to reduce the likelihood of a fall occurring, some carers even attempted to control their care recipients with dementia by physically confining them to a controlled space or restricting their freedom to move around. ${ }^{(23}$ While these preventive strategies appeared to reduce the risk of occurrence of falls and increase the carers' feeling of control, they can potentially contribute to greater dependence among older people. ${ }^{(18)}$

\section{DISCUSSION}

This integrative review identified the causes and impact of carers' concern about older persons falling at home. Six major themes were identified: (1) prevalence and measurement of fall concern; (2) carers' fall concerns; (3) impact on physical and psychological health; (4) lifestyle changes; (5) increased caregiving burden; and (6) impact on fall prevention strategies used. To provide a comprehensive review of carers' fall concern, studies related to Parkinson's disease, dementia and stroke were included in the review of the literature. Therefore, issues related to carers' concern may be aligned with the care recipients' medical condition that causes ambulation problems, rather than ageing frailty that leads to falls. The findings of this integrative review are pertinent for healthcare professionals in the investigation of carers' psychological well-being and other needs, as carers are often the people on the front line preventing the older person from falling at home.

The majority of carers in the studies reviewed reported being concerned about their care recipients falling again, ${ }^{(28,30)}$ and one study found that some carers were equally concerned even if the older persons had not fallen. ${ }^{(29)}$ This finding is similar to that of previous studies, which showed that older care recipients with no history of falling also experienced fear of falling, resulting in activity restriction, functional decline and an increased risk of admission to institutional care. ${ }^{(33-35)}$ Future research could explore more deeply the possible burden associated with carers' concern for non-fallers.

Most of the studies reviewed used a single-item instrument to measure carers' fall concern, and none described the statistical rigour for these instruments. ${ }^{(28-30)}$ On the basis of what the researchers have provided in their papers, it was not possible to determine the psychometric qualities associated with carers' concern. Since carers were essential partners in caring for the older person at home and falls have a significant impact on the carers' experience, a validated measure of carers' concern about the potential of falling in the older person could benefit fall surveillance. ${ }^{(36,37)}$

Besides having concerns about their care recipients falling, some carers also worried about the older person's non-adherence to fall prevention advice. ${ }^{(12,13,24,32)}$ It is possible that the older person fails to see the consequences of a fall, ${ }^{(38)}$ or feels that the advice to be careful about falling undermines their independence and freedom to engage in normal activities. ${ }^{(39)}$ Among carers, increased fall concern could be attributed to their lack of knowledge about fall prevention among older persons. It can also be suggested that carers who are overly concerned about falls may have inadvertently be restricting their care recipient's activities. ${ }^{(40)}$ Therefore, measuring the carers' level of fall concern provides insight into whether their personal resources are being stretched when caring for an older person at risk of falling. This interval measure could serve as an intervention point for healthcare professionals to provide education, skills training and support for carers to help them more effectively manage or prevent falls at home.

The use of fall prevention strategies, such as activity restriction and seclusion, indicates that carers may have limited knowledge about fall prevention. It also highlights a lack of provision of effective fall prevention services to people caring for older persons at risk of falling at home. Although physical restrictions such as seclusion are used to ensure safety, these measures could potentially have physical, psychological and social implications for the older person, as well as raise ethical issues related to human rights considerations. ${ }^{(41)}$ Since the carers have a major role in looking after the older persons at home, particularly in managing falls, their lack of knowledge and inappropriate use 
of fall prevention strategies could potentially endanger their care recipients. It is important to address these ethical issues to improve carers' awareness of fall risk and to avoid premature institutionalisation due to preventable falls.

\section{Implications to practice}

Recognising carers' concern can be incorporated into caregiver training, rehabilitation and fall prevention programmes to assist healthcare professionals to identify carers who might have difficulty in managing falls at home. Interventions could then be tailored to the individual carer and the older person. For instance, a distressed carer may be referred to a medical social worker or psychologist for counselling to ameliorate excessive concern. Information on access to resources and community services, such as home care assistance, respite care, counselling support and financial aids, could also be provided.

It is also important for healthcare professionals to identify carers' concern during discharge planning and to provide targeted discharge advice for older people admitted for recurrent falls. In countries with inadequate community services (i.e. nurses) to assist home carers in supporting the older person at risk of falling, it would be prudent to review the involvement of community nursing and care coordinators in the support of carers living at home with the older person at risk of falling.

\section{Recommendations for future research}

Many studies have focused on older people with specific medical conditions. Future studies are needed to further examine carers' concern for the general population of elderly people experiencing functional decline due to ageing, which puts them at risk of falling. A multi-item measure could be developed to effectively capture a comprehensive picture of the impact of an older person's fall on the carers, and this can be used as an alternative outcome measure for fall prevention programmes. ${ }^{(42)}$

Many carers experience lifestyle changes during the care of older people, which can aggravate physical and emotional burden. More research into how families can be better supported, especially in countries where families are considered the main support structure for older people, would be beneficial. ${ }^{(43)}$ For example, in some parts of the world, the family's children juggle with full-time jobs in addition to the care of their parents or other older family member. This situation often means that paid carers such as foreign domestic workers (FDWs) are engaged to help them. ${ }^{(43)}$ These FDWs are often lowly educated and poorly paid, regulated by only a work permit system binding them to an individual employer from one household. ${ }^{(43)}$ In this context, unlike a spouse or a relative, the FDWs have a paid duty to provide care for the older person living at home. Further research about paid carers' fall concern and support, and how family carers can be equipped to support and complement the roles of FDWs is crucial in the continuing care of the older person.

The majority of studies regarding falls and fall concern have been conducted in Western developed countries. Future research conducted in Asian cultures is recommended to allow for a detailed analysis of potential cultural influences on carers' fall concern. ${ }^{(36)}$ Such research could clarify and identify alternative approaches to the cultural care of older people at risk of falling who live at home. Fall concern research in Asian cultures could involve understanding filial responsibility and its profound influence on carers' fall concern and fall prevention strategies. Studies that include socioeconomic and environmental considerations related to fall prevention could also be worthy of deeper investigation.

\section{CONCLUSION}

Carers' concern about their care recipients falling is a major under-reported problem that can potentially affect carers' physical and psychological health and lifestyle, increasing their caregiving burden and influencing fall risk management at home. This concern is more than just the possibility of the older person falling and includes fear of the consequences of falling and the older person's lack of awareness of their fall risk. The apprehension associated with carers' concern regarding their care recipients' risk of falling could also reflect their lack of knowledge and understanding in fall risk and prevention. Evaluating carers' concern for their care recipients falling would provide an alternative perspective for healthcare professionals to understand the older person's fall risk and the carers' needs for further support at home.

\section{ACKNOWLEDGEMENT}

This research was supported by the Australian Government Research Training Programme Scholarship.

\section{SUPPLEMENTARY MATERIAL}

The Appendix is available online at https://doi.org/10.11622/ smedj.2019142.

\section{REFERENCES}

1. World Health Organization. Falls. Available at: http://www.who.int/ mediacentre/factsheets/fs344/en/. Accessed February 28, 2018.

2. World Health Organization. WHO global report on falls prevention in older age. Available at: http://www.who.int/ageing/publications/Falls_prevention7March. pdf. Accessed February 28, 2018.

3. Denkinger MD, Lukas A, Nikolaus T, Hauer K. Factors associated with fear of falling and associated activity restriction in community-dwelling older adults: a systematic review. Am J Geriatr Psychiatry 2015; 23:72-86.

4. United Nations Department of Economic and Social Affairs Population Division. World population prospects: the 2017 revision, key findings and advance tables. Available at: https://reliefweb.int/sites/reliefweb.int/files/resources/ WPP2017_KeyFindings.pdf. Accessed February 28, 2018.

5. Carers UK. Facts about carers 2015. Available at: https://www.carersuk.org/ images/Facts_about_Carers_2015.pdf. Accessed June 6, 2018.

6. National Alliance for Caregiving, AARP Public Policy Institute. Caregiving in the U.S. 2015 report. Available at: https://www.aarp.org/content/dam/aarp/ ppi/2015/caregiving-in-the-united-states-2015-report-revised.pdf. Accessed February 28, 2018

7. Australian Bureau of Statistics. Carers. Available at: http://www.abs.gov.au/ ausstats/abs@.nsf/Lookup/4430.0main+features402015. Accessed February 28, 2018

8. Mehta KK. A critical review of Singapore's policies aimed at supporting families caring for older members. J Aging Soc Policy 2006; 18:43-57.

9. Housing and Development Board, Singapore. Living with/near parents or child. Available at: https://www.hdb.gov.sg/cs/infoweb/residential/buying-a-flat/resale/ living-with-near-parents-or-married-child. Accessed October 18, 2018.

10. Teo P, Mehta K, Thang LL, Chan A. Ageing in Singapore: service needs and the state. London: Routledge, 2006.

11. Department of Statistics, Singapore. Families and households in Singapore, 2000-2014. Available at: https://www.singstat.gov.sg/find-data/search-by-theme/ 
households/households/external-sources. Accessed October 18, 2018

12. Faes MC, Reelick MF, Joosten-Weyn Banningh LW, et al. Qualitative study on the impact of falling in frail older persons and family caregivers: foundations for an intervention to prevent falls. Aging Ment Health 2010; 14:834-42.

13. Davey C, Wiles R, Ashburn A, Murphy C. Falling in Parkinson's disease: the impact on informal caregivers. Disabil Rehabil 2004; 26:1360-6.

14. Kuzuya M, Masuda Y, Hirakawa Y, et al. Falls of the elderly are associated with burden of caregivers in the community. Int J Geriatr Psychiatry 2006; 21:740-5.

15. Mackintosh S, Fryer C, Sutherland M. For falls sake: older carers' perceptions of falls and falls risk factors. Intern J Allied Health Sci Pract 2007; 5:1-9.

16. Potter P, Pion S, Klinkenberg D, Kuhrik M, Kuhrik N. An instructional DVD fall-prevention program for patients with cancer and family caregivers. Oncol Nurs Forum 2014; 41:486-94.

17. Taylor ME, Lord SR, Brodaty $\mathrm{H}$, et al. A home-based, carer-enhanced exercise program improves balance and falls efficacy in community-dwelling older people with dementia. Int Psychogeriatr 2017; 29:81-91.

18. Honaker JA, Kretschmer LW. Impact of fear of falling for patients and caregivers: perceptions before and after participation in vestibular and balance rehabilitation therapy. Am J Audiol 2014; 23:20-33.

19. Fitzgerald TG, Hadjistavropoulos T, MacNab YC. Caregiver fear of falling and functional ability among seniors residing in long-term care facilities. Gerontology 2009; 55:460-7.

20. Whittemore R, Knafl K. The integrative review: updated methodology. J Adv Nurs 2005; 52:546-53.

21. Pluye P, Robert E, Cargo $M$, et al. Proposal: a mixed methods appraisal tool for systematic mixed studies reviews. Available at: http:// mixedmethodsappraisaltoolpublic.pbworks.com. Accessed February 28, 2018.

22. Abendroth M, Lutz BJ, Young ME. Family caregivers' decision process to institutionalize persons with Parkinson's disease: a grounded theory study. Int J Nurs Stud 2012; 49:445-54

23. Buri H, Dawson P. Caring for a relative with dementia: a theoretical model of coping with fall risk. Health Risk Soc 2000; 2:283-93.

24. Kelley CP, Graham C, Christy JB, et al. Falling and mobility experiences of stroke survivors and spousal caregivers. Phys Occup Ther Geriatr 2010; 28:235-48.

25. Peach T, Pollock K, van der Wardt V, et al. Attitudes of older people with mild dementia and mild cognitive impairment and their relatives about falls risk and prevention: a qualitative study. PLoS One 2017; 12:e0177530.

26. Habermann B, Shin JY. Preferences and concerns for care needs in advanced Parkinson's disease: a qualitative study of couples. J Clin Nurs 2017; 26:1650-6.

27. Stevenson M, Taylor BJ. Risk communication in dementia care: family perspectives. J Risk Res 2018; 21:692-709.

28. Faes MC, Reelick MF, Melis RJ, et al. Multifactorial fall prevention for pairs of frail community-dwelling older fallers and their informal caregivers: a dead end for complex interventions in the frailest fallers. J Am Med Dir Assoc 2011; 12:451-8.

29. Forster A, Young J. Incidence and consequences of falls due to stroke: a systematic inquiry. BMJ 1995; 311:83-6.

30. Liddle J, Gilleard C. The emotional consequences of falls for older people and their families. Clin Rehabil 1995; 9:110-4.

31. Meyer C, Dow B, Bilney BE, et al. Falls in older people receiving in-home informal care across Victoria: influence on care recipients and caregivers. Australas J Ageing 2012; 31:6-12.

32. Dow B, Meyer C, Moore KJ, Hill KD. The impact of care recipient falls on caregivers. Aust Health Rev 2013; 37:152-7.

33. Scheffer AC, Schuurmans MJ, van Dijk N, van der Hooft T, de Rooij SE. Fear of falling: measurement strategy, prevalence, risk factors and consequences among older persons. Age Ageing 2008; 37:19-24.

34. Cumming RG, Salkeld G, Thomas M, Szonyi G. Prospective study of the impact of fear of falling on activities of daily living, SF-36 scores, and nursing home admission. J Gerontol A Biol Sci Med Sci 2000; 55:M299-305.

35. Hughes CC, Kneebone II, Jones F, Brady B. A theoretical and empirical review of psychological factors associated with falls-related psychological concerns in community-dwelling older people. Int Psychogeriatr 2015; 27:1071-87.

36. Ang SGM, Wilson A, O'Brien AP. Caregivers' falls concern for older persons in the Singapore community. GSTF J Nurs Health Care 2018; 5:1-5.

37. Ang SGM, O'Brien AP, Wilson A. Fall concern about older persons shifts to carers as changing health policy focuses on family, home-based care. Singapore Med J 2018; 59:9-11.

38. Lim ML, Ang SGM, Teo KY, et al. Patients' experience after a fall and their perceptions of fall prevention: a qualitative study. J Nurs Care Qual 2018; 33:46-52.

39. McMahon S, Talley KM, Wyman JF. Older people's perspectives on fall risk and fall prevention programs: a literature review. Int J Older People Nurs 2011; 6:289-98.

40. Ang SGM, Wilson A, O'Brien AP. Concern of older people falling. Aust Nurs Midwifery J 2018; 25:36.

41. Scheepmans K, Dierckx de Casterlé B, Paquay L, Milisen K. Restraint use in older adults in home care: a systematic review. Int J Nurs Stud 2018; 79:122-36.

42. Moore DS, Ellis R. Measurement of fall-related psychological constructs among independent-living older adults: a review of the research literature. Aging Ment Health 2008; 12:684-99.

43. Yeoh BS, Huang S. Foreign domestic workers and home-based care for elders in Singapore. J Aging Soc Policy 2009; 22:69-88. 


\section{APPENDIX}

Supplementary Table I. Full search strategy and search terms used.

\begin{tabular}{|c|c|c|c|c|c|c|c|}
\hline No. & Search & CINAHL $^{a}$ & Embase & Medline & Psyinfo & Scopus $^{b}$ & Web of Science \\
\hline 1 & caregiver* & 53,513 & 93,852 & 64,582 & 51,194 & 92,895 & 61,032 \\
\hline 2 & support person* & 5,467 & 1,553 & 1,234 & 1,234 & 2,764 & 1,573 \\
\hline 3 & carer* & 11,441 & 18,732 & 12,692 & 9,318 & 19,464 & 14,327 \\
\hline 4 & fall $^{*}$ adj3 efficac* & 564 & 1,160 & 797 & 480 & 1,075 & 895 \\
\hline 5 & fear* adj3 fall* & 1,066 & 2,182 & 1,496 & 673 & 1,981 & 1,753 \\
\hline 6 & worr* adj3 fall* & 19 & 47 & 29 & 17 & 61 & 46 \\
\hline 7 & concern* adj3 fall* & 278 & 501 & 345 & 188 & 996 & 612 \\
\hline 8 & 1 or 2 or 3 & 65,151 & 106,244 & 73,812 & 58,153 & 108,584 & 73,776 \\
\hline 9 & 4 or 5 or 6 or 7 & 1,615 & 3,209 & 2,227 & 1,091 & 3,537 & 2,836 \\
\hline 10 & 8 and 9 & 52 & 86 & 60 & 47 & 75 & 56 \\
\hline 11 & Limit to English language & 50 & 83 & 58 & 44 & 70 & 54 \\
\hline
\end{tabular}

Replace adj3 with n3; ${ }^{\mathrm{b}}$ Replace adj3 with w/3; ${ }^{\mathrm{C}}$ Replace adj3 with near/3 